\title{
A supernumerary tooth in the nose: A case analysis from the Kayalıpınar (Hellenistic-EarlyByzantian) population, Sivas, Turkey
}

\author{
İbrahim Sarı ${ }^{*} \odot$, Ayşen Açıkkol ${ }^{2} \odot$ \\ 'Dr. | Independent researcher, Sivas - Turkey \\ ${ }^{2}$ Prof. Dr. | Sivas Cumhuriyet University, Department of Anthropology, Sivas - Turkey
}

\begin{abstract}
The paper reports on research into a nasal tooth sample belonging to a

12-years-old child excavated from the Kayalıpinar archaeological site in Sivas province, Turkey. The individuals of Kayalıpinar were dated between the Hellenistic-Early Byzantine periods. In the anthropological analysis of the child, a supernumerary tooth defined as inverted mesiodens on the maxilla was encountered. The tooth had an amorphous structure, the tooth root was very short and the tooth crown extended into the nasal cavity. The latest feature proves that it is a supernumerary nasal tooth. This evaluation is in parallel with similar studies.
\end{abstract}

Key Words: Kayalıpınar, Hellenistic-Early Byzantian, nasal tooth, supernumerary tooth, inverted mesiodens, intranasal tooth

\section{Introduction}

The supernumerary tooth is defined as the excess of normal number of teeth in deciduous and permanent dentition (Alt and Türp, 1998). These additional teeth consist of a dental crown that can be formed in an uncommon morphology, and these teeth can be either in vertical, horizontal or inverted position (Chen et al., 2002; Arunkumar et al., 2007). They may be similar or might differ from the normal teeth in terms of their shapes and sizes (Kohli and Verma, 1970). They are seen in the permanent dentition in the anterior and molar maxillar regions and in the premolar region of the mandible (Alt and Türp, 1998). The supernumerary teeth are associated with ontogenetic developmental disorders of the oral area (Alt, 1990).

The most important intranasal teeth in humans are supernumerary teeth (Prasad et al., 2011). Mesiodens is the most common supernumerary tooth (Alt, 1990), and often takes place around the incisors on the maxilla (Moreano et al., 1998; Chen et al., 2002). Moreover, it
* Sorumlu Yazar / Corresponding Author: İbrahim Sarı Independent Researcher Sivas / Turkey

E-posta: paleoibrahim@gmail.com
Alındı/Received: 3 Ağustos / August 2021 Düzeltildi/Revised: 7 Ekim / October 2021 Kabul/Accepted: 7 Ekim / October 2021 Yayımlandı/Published: 28 Aralık / December 2021
Burunda süpernumerer bir diş: Kayalıpınar (HellenistikErken Bizans) toplumunda bir vaka incelemesi

$\ddot{O} z$

Bu çalısma, Sivas Ili Kayalıpmar arkeolojik kazılarndan açı̆a çıkarlan 12 yaşındaki bir çocuğa ait burun dişi örneğini rapor etmektedir. Kayahpınar insanlar Hellenistik-Erken Bizans dönemleri arasina tariblendirilmistir. Cocuğun antropolojik analizinde, üst çene de ters meziodens olarak tanmlanan süpernümerer

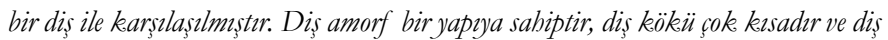
tacı burun boșluğuna doğru uz̧anmaktadrr. Dişin bu son özelliği onun süpernümerer bir burun dişi olduğunu kanutlamaktadır. Bu değerlendirme benzer çalısmalarla paralellik göstermektedir.

Anahtar Sözcükler: Kayalipmar, Hellenistik-Erken Bizans, burun disi, süpernümerer diş (ters meziodens), burun içi diṣ.

may extend into the nasal cavity if the growth direction of the tooth is anti-craniocaudal, such a situation is expressed as nasal tooth (Alt, 1990) or intranasal tooth (Prasad et al., 2011). Although the etiology is not clear, trauma, osteomyelitis, dental infection, cysts, developmental disorders such as arrested eruption of tooth, and cleft palate may be associated with intranasal teeth (Prasad et al., 2011).

This study focuses on a new case of supernumerary tooth, which was not widely known in the ancient Anatolian populations and whose incidence was reported only in two prior studies. The aim of the present study is to investigate whether the case analyzed in this study is coherent with other studies and to make an evaluation about its possible etiology.

\section{Materials and methods}

The study sample consisted of human skeletal remains excavated from the Kayalipinar site that is dated between the Hellenistic-Early Byzantine period in 
Sivas (Müller-Karpe and Müller-Karpe, 2012). The age of the individual was determined according to the time of the tooth eruption (Ubelaker, 1991; Sağır, 2013). The sex was not determined due to the individual being a subadult. Before the analysis, the radiological view of the maxilla was taken in the Department of Clinical Sciences, Department of Prosthodontics, with the permission of Professor Derya Özdemir Doğan from Sivas Cumhuriyet University Faculty of Dentistry.

\section{Results}

The individual, who is the focus of this study, was recorded with the grave number 10 and was a 12 -yearsold child. The child was found in a grave surrounded with mudbrick. As in some other graves, the skeletal materials that belong to this individual were also damaged due to agricultural activities and soil erosion. Although the skeleton was not complete, there were enough bones available for the analysis.

An extra tooth on the maxilla as well as twenty nine permanent teeth on the sample were encountered. This extra tooth was located in the root area of the upper left central incisor (Figure 1a). It is not known whether this condition was symmetrical or not because of the partial damage of the upper right jaw. The extra tooth had an amorphous view, in the form of a cone and completed its crown-root development. The enamel layer and pulp chamber of the tooth can be easily distinguished with the radiological view (Figure 1b). The tooth lied cross in the jaw. Contrary to the normal growth direction (craniocaudal), the crown was located in the floor of the nasal cavity (meatus nasi inferior) (Figure 1c). The total tooth height was $12.94 \mathrm{~mm}$ and the root height was very short (Figure $1 \mathrm{a}$ and $1 \mathrm{~b})$. The positions of the maxillary anterior teeth and their eruptions were not found affected by the extra tooth.

According to the paleopathological preliminary analysis, there were cribra orbitalia on the right orbit (left side is missing) and a circular pit caused by a blunt trauma near the right tuber parietale. Nevertheless, any evidence of porotic hyperostosis and/or porous condition on cranial bones were not noticed. In addition, periostitis was observed in some of the long bones such as the femur and tibia. Finally, there was calculus and slight dental wear on the teeth, no caries, abscess and enamel hypoplasia.

\section{Discussion}

The study aimed to analyze the supernumerary tooth from the Kayalipinar population and to discuss the interpretation of the form of occurrence and presence of the case by anthropological and clinical studies.

It was noticed that the cases were similar in itself from many perspectives, but were also interpreted under

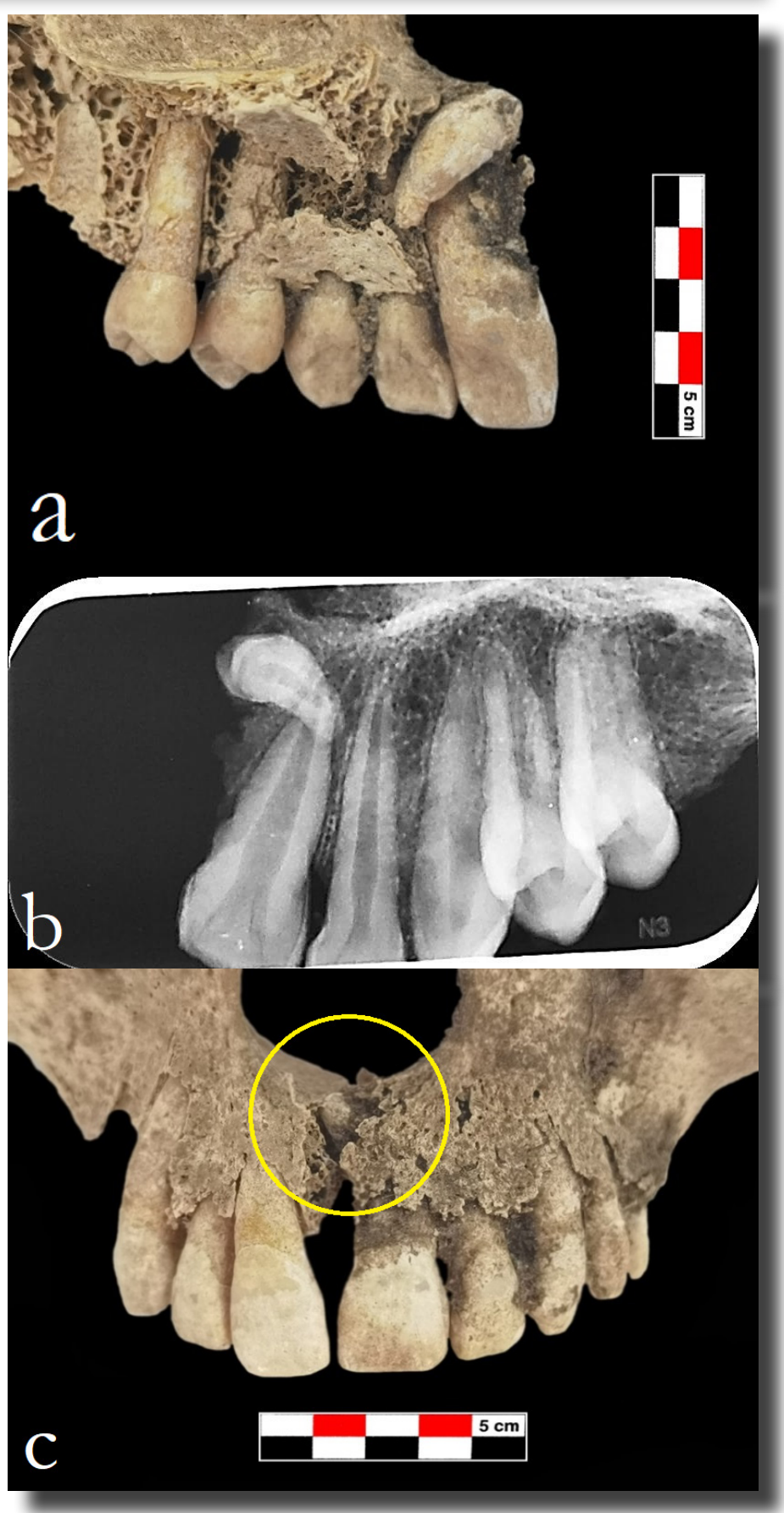

Figure 1. a. Lingual view of the left maxilla, $b$. Radiological view of the tooth, c. Location of the nasal tooth in the maxilla (in yellow circle)

different names in the literature review. In other words, while a case is defined as "nasal tooth" in anthropological studies, they are presented as "supernumerary tooth in the nose" (Öztürk et al., 2007) or "intranasal tooth" (Prasad et al., 2011) in clinical studies. As stated in the study of Alt (1990), a tooth reaching into the nasal cavity of the dental crown is seen as evidence of a "nasal tooth". There are also researchers who consider it sufficient to be only in or around the nasal cavity as well as those who emphasize the orientation of the dental crown in clinical studies on this subject (Kohli and Verma, 1970; Nastri and Smith, 1996; Chen et al., 2002). 
The nasal teeth were caused by ectopic eruption of supernumerary teeth and different symptoms may be observed in such cases (Chen et al., 2002). It has been reported in clinical studies that there are patients with no symptoms as much as there are patients with symptoms (Moreano et al., 1998; Prasad et al., 2011). In clinical cases, as there may be nasal obstruction, nasal bleeding, runny nose, nasal swelling, chronic sinusitis, speech problems, malodour, septal abscess, headache etc. due to the nasal tooth, there may be patients without any symptoms as well (Kohli and Verma, 1970; Nastri and Smith, 1996; Arunkumar et al., 2007; Öztürk et al., 2007). While genetic and environmental factors are more prominent and prioritized on the etiology of supernumerary teeth (Prasad et al., 2011), one of the most logical and acceptable theories is that these teeth developed from the remnants of epithelial fragments that were dispersed during tooth development (Alt, 1990).

Prasad et al. (2011) reported that a problem in the development of the tooth bud or a problem in the orientation/movement path of the tooth bud may cause the intranasal tooth. According to Özer et al. (2016), the effect of trauma, infection, anatomical disorder and genetic factors on nasal tooth formation are emphasized. In a clinical study, it was stated that trauma did not have an effect on the nasal tooth (Uysal et al., 2010), while another study reported that trauma may be among the possible causes of nasal tooth formation (Mushtaq and Kalgotra, 2017).

There are only two dental studies on the ancient Anatolian populations whose samples are considered as nasal tooth. The first of these was found in Havuzdere (Medieval Age) in two individuals, a female and a child. The upper left central incisor of a female, aged 45-50, extended into the nasal cavity. In addition, the crown and root of this tooth had a distinct angle in neck region of the tooth. The upper left canine of another 15-years-old individual, whose root has not been formed, reflected the characteristic of a nasal tooth at the developmental stage (Özer et al., 2016). İznik (Late Byzantine) is the second population which had a nasal tooth as a canine-like tooth on the maxilla of one of the population members. The crown of this tooth had moved on up to the nasal cavity (Erdal, 1996).

In the paleopathological examination of the Havuzdere female, the schmorl nodule and osteophytes in the vertebrae, as well as jaw and dental diseases were detected. In the 15-years-old child, hypoplasia and calculus were observed in the teeth in addition to the cribra orbitalia on the right orbit (Özer et al., 2016). There is no mention of any paleopathological data for the İznik sample. The paleopathological data of the 12-years-old Kayalıpinar child are already reported above. Accordingly, healed blunt trauma, periostitis and presence of severe cribra orbitalia indicate that the child is exposed to a serious environmental stress during the growth period.

The supernumerary tooth sample in this study is located at the floor of the nasal cavity. Although the preservation state of the area where the tooth is located is not very good, it is seen that a small part of the dental crown is located in the nose. It is not possible to determine whether the child was aware of the presence of this extra tooth (inverted mesiodens), there were any signs/symptoms caused by this tooth, or the tooth was surrounded by mucosa or granular tissue while the child is alive.

The case sample discovered in Kayalıpinar is a supernumerary tooth and it exactly overlaps with the definition of mesiodens due to its location. According to Schuurs (2013), a significant part of the teeth that are considered as mesiodens are reverse oriented and a very small part is located in the cross direction. This information is consistent with the findings obtained in this research. However, samples with similar features in bioarchaeological and some clinical studies were interpreted as "nasal tooth" (Alt, 1990; Erdal, 1996; Nastri and Smith, 1996; Chen et al., 2002; Arunkumar et al., 2007; Özer et al., 2016). All these data have made it obligatory to evaluate the Kayalipinar tooth sample as a "supernumerary nasal tooth".

\section{Conclusion}

Deciduous, permanent and supernumerary teeth could be nasal teeth. The tooth examined in this study shows the feature of a supernumerary nasal tooth as well. Though there are many factors about supernumerary teeth and the etiology of it in the literature, genetic and environmental factors come forward. There is not any information concerning the genetic and familial history of the Kayalipinar people, but the presence of dental anomalies such as impacted teeth, absence of congenital teeth, enamel pearl and fusion (Sar1 and Aç1kkolYlldirlm, 2021) indicate that the genetic structure should be considered as well as the other factors. It is clear that the child have a healed blunt trauma affecting the skull (on tuber parietale), though it is unfeasible to determine the age of the trauma. Unfortunately, it is also impossible to know whether this healed trauma affected the facial bones, and if so, the possible degree of impact on the nasal tooth.

In sum, many nasal teeth have been reported under different names in clinical studies. In the ancient Anatolian populations, it was reported in only two populations and three individuals. Unfortunately, due to this insufficient comparison data, the nasal tooth in the Kayalıpınar child was mainly compared with 
clinical studies and these two populations. As a result, the Kayalipinar case is defined as "supernumerary nasal tooth" and this study is found important in terms of providing the opportunity to compare with other possible nasal tooth cases.

\section{References}

Alt, K. W. (1990). Nasal teeth: Report of a historic case. International Journal of Anthropology, 5(3), 245-249. https://doi. org $/ 10.1007 / \mathrm{BF} 02446250$

Alt, K.W., \& Türp, J.C. (1998). Hereditary dental anomalies. in K.W. Alt, F.W. Rösing and M. Teschler-Nicola (Eds.), Dental anthropology: Fundamentals, limits, and prospects (pp. 95-128). Springer-Verlag. https://doi.org/10.1007/978-3-7091-7496$\underline{87}$

Arunkumar, J. S., Prasad, K. C., \& Shanthi, N. (2007). Nasal teeth: A case report. Indian Journal of Otolaryngology and Head \& Neck Surgery, 59, 197-198. https://doi.org/10.1007/s12070-0070060-Z

Chen, A., Huang, J. K., Cheng, S. J., \& Sheu, C.Y. (2002). Nasal teeth: Report of three cases. American Journal of Neuroradiology, 23(4), 671-673. http://www.ajnr.org/content/ajnr/23/4/671.full. pdf

Erdal, Y. S. (1996). İznik Geç Biz̧ans dönemi insanlarmm çene ve dişlerinin antropolojik açudan incelenmesi [Anthropological analyses of jaws and teeth of Nicaea Late Byzantine population] [Unpublished PhD dissertation]. Hacettepe Üniversitesi, Ankara.

Kohli, G. S., \& Verma, P. L. (1970). Ectopic supernumerary tooth in the nasal cavity. The Journal of Laryngology \& Otology, 84(5), 537-538. https://doi.org/10.1017/s0022215100072200

Moreano, E. H., Zich, D. K., Goree, J. C., \& Graham, S.M. (1998). Nasal tooth. American Journal of Otolaryngology, 19(2), 124-126. https://doi.org/10.1016/s0196-0709(98)90108-9

Mushtaq, M., \& Kalgotra, S. (2017). Ectopic eruption of maxillary central incisor in the nasal cavity: A rare case report. International Journal of Dentistry Research, 2(1), 12-14. https:// doi.org/10.31254/dentistry.2017.2104

Müller-Karpe, V., \& Müller-Karpe, A. (2012). Kayalıpınar'da yapılan araştırmalar [The research in Kayalipınar]. Arastırma Sonuclar Toplantısi, 29(2), 407-418. https://kvmgm.ktb.gov.tr/ Eklenti/4649,29arastirma2.pdf?0

Nastri, A.L., \& Smith, A. C. (1996). The nasal tooth. Case report. Australian Dental Journal, 41(3), 176-177. https://doi. org/10.1111/j.1834-7819.1996.tb04851.x

Özer, İ., Sağır, M., Karatufan, A., \& Şahin, S. (2016). Havuzdere iskeletlerinin paleoantropolojik analizi: Burun dişi örnekleri [The paleoanthropological analyses of Havuzdere skeletons: Nasal tooth samples]. Arkeometri Sonuclar Toplantısi, 31, 8592. https://kvmgm.ktb.gov.tr/Eklenti/45226,31arkeometri. pdf?0

Öztürk, C., Eryılmaz, K., \& Çakur, B. (2007). Supernumerary tooth in the nose. Turkish Journal of Medical Sciences, 37(4), 227-230. https://journals.tubitak.gov.tr/medical/issues/sag07-37-4/sag-37-4-8-0702-5.pdf
Prasad, G. R., Nair, P. P., Gharote, H., Hegade, K., Agarwal, K., \& Jain, A. (2011). Intranasal tooth: An ectopic eruption of mesiodens in nasal cavity - A case report and review. Journal of Indian Academy of Oral Medicine and Radiology, 23(3), 252-255. https://doi.org/10.5005/jp-journals-10011-1140

Sağır, S. (2013). Dişlerin çıkıs ve gelişim aşamalarından yas tahmini metodu olusturulmast [Development of age estimation method from stage of eruption and growth of the teeth] [Unpublished PhD dissertation]. Ankara Üniversitesi, Ankara.

Sarı, İ., \& Açıkkol-Yıldırım, A. (2021). Eski toplumlarda diş anomalileri: Kayalıpınar örneği [Dental anomalies in ancient populations: The Kayalipinar samples]. Antropoloji, 41, 99107. https://doi.org/10.33613/antropolojidergisi.883636

Schuurs, A. (2013). Pathology of the hard dental tissues. Wiley-Blackwell. https://doi.org/10.1002/9781118702659

Ubelaker, D. H. (1991). Human skeletal remains: Excavations, analysis, interpretation, Second edition. Taraxacum.

Uysal, S., Kansu, Ö., \& Kansu, H. (2010). Supernumerary tooth in the nasal cavity: Case report. Hacettepe Dis Hekimliği Fakültesi Dergisi, 34(3-4), 42-45.

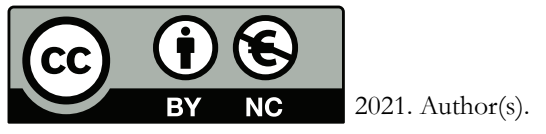

This work is an open access article published under Creative Commons AttributionNonCommercial (CC BY-NC 4.0) license. 